\title{
KAJIAN IMPLEMENTASI STUDI MATEMATIKA PADA KELAS INKLUSI DI SMPN 10 PEKALONGAN
}

\author{
Drajat Stiawan
}

\author{
IAIN Pekalongan \\ e-mail: drajatstiawan@gmail.com
}

\begin{abstract}
Abstrak
Penelitian ini bertujuan untuk mendeskripsikan pelaksanaan pembelajaran matematika pada kelas inklusi di SMP N 10 Kota Pekalongan. Metode penelitian yang digunakan adalah menggunakan metode deskriptif dengan pendekatan kualitatif. Teknik yang digunakan dalam pengumpulan data meliputi: teknik observasi, wawancara dan dokumentasi. Sedangkan teknik analisis data meliputi pengumpulan data, reduksi data, penyajian data dan penarikan kesimpulan. Pada tahun pelajaran 2017/2018 di SMPN 10 Pekalongan terdapat total 19 siswa berkebutuhan khusus, dengan rincian 7 siswa berkebutuhan khusus pada kelas VII, 6 siswa berkebutuhan khusus pada kelas VIII, dan 6 siswa berkebutuhan khusus pada kelas IX. Hasil penelitian ini didapat bahwa (1) pelaksanaan pembelajaran matematika bagi siswa reguler dan siswa berkebutuhan khusus bersama dalam satu kelas; (2) Guru matematika pada pelaksanaan pembelajaran sudah mengkondisikan siswa baik secara fisik maupun psikis; (3) Metode dan media pembelajaran sama antara siswa reguler dan berkebutuhan khusus; dan (4) Kegiatan evaluasi melalui tes tertulis maupun lisan ketika satu bahasan selesai.
\end{abstract}

Kata kunci: Matematika, Pembelajaran, Kelas Inklusi

\begin{abstract}
This study aims to describe the implementation of mathematics learning in inclusive classes in SMP N 10 Pekalongan City. The research method used is descriptive method with a qualitative approach. The techniques used in data collection include observation, interview, and documentation techniques. While data analysis techniques include data collection, data reduction, data presentation, and conclusion drawing. In the 2017/2018 school year at Pekalongan 10 Middle School, there were a total of 19 students with special needs, with details of 7 students with special needs in class VII, 6 students with special needs in class VIII, and 6 students with special needs in class IX. The results of this study found that (1) Implementation of mathematics learning for regular students and students with special needs together in one class; (2) Mathematics teachers in the implementation of learning have conditioned students both physically and psychologically; (3) Learning methods and media are the same between regular students and special needs; and (4) Evaluation activities through written or oral tests when one discussion is finished.
\end{abstract}

Keywords: Mathematics, Learning, Inclusive Class 


\section{PENDAHULUAN}

Pendidikan inklusi menurut Ilahi (2013: 26) merupakan layanan pendidikan yang mengikutsertakan anak berkebutuhan khusus belajar bersama dengan anak normal sebayanya di sekolah regular. Anak Berkebutuhan Khusus (ABK) adalah anak dengan kepemilikan karakteristik khusus yang berbeda dengan anak lainnya pada umumnya menunjukan pada ketidakmampuan mental, emosi atau fisik (wiyani, 2014:17). Sedangkan berdasarkan Permendiknas No. 70 tahun 2009, pasal 1 bahwa pendidikan inklusi merupakan sistem penyelenggaraan pendidikan yang memberikan kesempatan kepada semua peserta didik yang memiliki kelainan dan memiliki potensi kecerdasan dan atau bakat istimewa untuk mengikuti pendidikan atau pembelajaran dalam satu lingkungan pendidikan secara bersama-sama dengan peserta didik pada umumnya. Dengan demikian anak-anak dengan kebutuhan khusus seperti tunanetra, tunarungu, slow learner, tunadaksa, tunalaras, dan anak-anak berkesulitan belajar juga memiliki kesempatan yang sama untuk memperoleh pendidikan.

Pendidikan inklusi mempasilitasi siswa berkebutuhan khusus dididik bersama-sama siswa lainnya (normal), untuk mengoptimalkan potensi yang dimilikinya, yang mana pendidikan inklusi ini merupakan sekolah yang diperuntukkan bagi semua siswa, tanpa melihat kondisi fisiknya. Hal ini dilandasi kenyataan bahwa dalam masyarakat terdapat keberagaman yang tidak dapat dipisahkan sebagai satu komunitas, dan keberagaman itu justru akan menjadi kekuatan bagi kita untuk menciptakan suatu dorongan untuk saling mengahargai, saling menghormati, dan toleransi (Jerami, 2007:65). Hal ini sesuai dengan pendapat Praptiningrum (2010) bahwa pendidikan inklusif merupakan suatu system layanan pendidikan yang mensyaratkan agar anak berkebutuhan khusus dilayani disekolahan terdekat dikelas biasa bersama teman-teman seusianya. Jadi pada prinsipnya pendidikan inklusi adalah pendidikan yang mengoptimalkan serta mengikutsertakan siswa yang mempunyai keterbatasan atau anak berkebutuhan khusus (ABK) dalam kelas reguler tanpa memandang kekurangan peserta didik. Semua siswa menerima pembelajaran yang sama tanpa dibedakan satu sama lain, sehingga setiap siswa dapat berpartisipasi penuh dalam proses pembelajaran.

Penyelenggaraan pendidikan inklusi ini diharapkan mampu menjadi solusi agar anak yang berkebutuhan khusus tetap mengenyam pendidikan. Namun beberapa permasalahan yang muncul terkait penyelenggaraan kelas inklusi adalah ketersediaan tenaga pendidik masih belum sesuai dengan pedoman penyelenggaraan pendidikan inklusif, karena sebagian sekolah inklusif belum memperoleh dukungan guru pembimbing khusus maupun tenaga ahli. Padahal penyelenggaraan sekolah inklusi memerlukan guru atau tenaga pendidik yang memiliki kemampuan khusus. Menurut Praptiningrum (2010) Kemampuan khusus tersebut adalah (1) Pengetahuan tentang perkembangan anak 
berkebutuhan khusus, (2) Pemahaman akan pentingnya mendorong rasa penghargaan anak berkaintan dengan perkembangan, motivasi dan belajar melalui suatu interaksi positif dan berorientasi pada sumber belajar, (3) Pemahaman tentang konvensi hak anak dan implikasinya terhadap implementasi pendidikan dan perkembangan semua anak, (4) Pemahaman tentang pentingnya menciptakan lingkungan yang ramah terhadap pembelajaran yang berkaitan dengan isi, hubungan sosial, pendekatan dan bahan pembelajaran, (5) Pemahaman arti pentingnya belajar aktif dan pengembangan pemikiran kreatif dan logis, (6) Pemahaman pentingnya evaluasi dan assesmen berkesinambungan oleh guru, (7) Pemahaman konsep inklusi dan pengayaan serta cara pelaksanaan inklusi dan pembelajaran yang berdeferensi, (8) Pemahaman terhadap hambatan belajar termasuk yang disebabkan oleh kelainan fisik maupun mental, (9) Pemahaman konsep pendidikan berkualitas dan kebutuhan implementasi pendekatan dan metode baru.

Pelaksanaan pendidikan inklusi seharusnya mampu menciptakan suasana yang menyenangkan, ramah, fleksibel dan mampu menumbuhkan rasa percaya diri pada siswa. Kenyataan dilapangan belum sesuai dengan pedoman penyelenggaraan pendidikan inklusi, baik dari segi kondisi siswa, kualifikasi guru,serta sarana dan prasarana penunjang (Praptiningrum, 2010). Namun demikin permasalahan bisa saja muncul di kelas inklusi.

Beberapa permasalahan yang muncul dengan model kelas inklusi adalah kurangnya guru pendamping khusus. Ketersediaan guru pendamping khusus yang kurang akan berpengaruh terhadap kelancaran proses pembelajaran khususnya bagi siswa berkebutuhan khusus. Permasalahan lain adalah terkait dengan penerapan metode yang pas untuk menyampaikan materi pembelajaran kepada siswa reguler dan siswa berkebutuhan khusus. Hal ini disebabkan tidak semua guru punya skill untuk mengajarkan materi pada siswa yang didalam kelas ada siswa berkebutuhan khusus. Sehingga memunculkan dilema bagi guru. Supaya permasalahan tersebut bisa teratasi maka menurut Sunanto \& Hidayat (2016) perlu mengadakan pra-kondisi yakni minimal 1) ada pemahaman konsep pendidikan inklusi yang benar, 2) ada penerimaan tentang pendidikan inklusi oleh warga sebagai strategi untuk memberikan akses pendidikan yang lebih baik bagi $A B K, 3)$ guru memiliki kompetensi menangani dan mengajar $A B K, 4)$ tersedia sumbersumber dukungan disekitar sekolahan, dan 5) mendapat dukungan warga sekolah dan masyarakat dan sebagainya.

SMPN 10 Pekalongan merupakan salah satu sekolahan yang melaksanakan program inklusi. Hal ini berdasarkan keputusan dari Dinas Pendidikan Kota Pekalongan, sejak tahun 2011 SMPN 10 ditunjuk oleh pemerintah pusat sebagai sekolah dengan sistem pendidikan inklusi. Pelaksanaan program kelas inklusi di SMPN 10 dimulai sejak tahun pelajaran 2011/2012 yakni melayani siswa dengan kebutuhan khusus dalam hal ini adalah C1-Tuna grahita maupun slowlearner (anak lamban belajar).Tuna grahita 
berhubungan dengan masalah perkembangan kemampuan kecerdasan yang rendah dan merupakan sebuah kondisi (Endang, Rochyadi, Alimin, dan Zaenal, 2005:11). Sedangkan slowlearner adalah anak yang memiliki potensi kecerdasan sedikit dibawah normal. Namun mereka tidak termasuk anak tuna grahita. Anak yang dikategorikan slowlearner biasanya mempunyai prestasi yang rendah serta daya tangkap terhadap materi pelajaran lambat.

Jumlah peserta didik kelas VII 174 pada tahun ajaran 2017/2018, kelas VIII sejumlah 163 siswa, dan kelas IX sejumlah 151 siswa. Jumlah total siswa berkebutuhan khusus ada 19 siswa, dengan rincian sebagai berikut terdapat 7 siswa berkebutuhan khusus pada kelas VII, selanjutnya 6 siswa berkebutuhan khusus pada kelas VIII, dan 6 siswa berkebutuhan khusus pada kelas IX. Pengkategorian siswa ABK atau siswa regular melalui hasil penelitian yakni pertama ada yang sudah terdeteksi sejak Sekolah Dasar dan ketika mendaftar sudah tercantum keterangan tersebut, maka otomatis pihak sekolah akan memperlakukan sebagaimana mestinya, Kedua, terkadang anak pada usia Sekolah Dasar masih belum terdeteksi bahwa sebenarnya anak tersebut merupakan ABK dan baru terdeteksi ketika sudah masuk jenjang SMP, maka jika dari pihak SMPN 10 mendeteksi keadaan tersebut hal yang pertama dilakukan adalah melakukan tes psikologi yang apabila ternyata benar anak tersebut merupakan ABK maka akan diperlakukan sama seperti $A B K$ yang lain dan pemberitahuan terhadap orang tua sang anak.

Penelitian tentang penyelenggaraan sekolah inklusi telah dilakukan oleh beberapa peneliti sebelumnya, yakni oleh Fitria (2012), Tarjiah (2015), riset ini mengkaji tentang pengembangan model pembelajaran matematika bagi siswa berkesulitan belajar khususnya di sekolah dasar inklusi. Meskipun sama-sama mengkaji kelas inklusi tetapi ada perbedaan pada fokus dan lokus kajiannya. Penelitian ini mengkaji bagaimana pembelajaran matematika di sekolah inklusi, khususnya tentang pelaksanaan pembelajaran, metode dan evaluasi pembelajarannya. Hal ini tentu saja menarik mengingat dalam sekolah inklusi terdiri dari siswa yang kategori normal bersatu atau bercampur dengan siswa berkebutuhan khusus. Hasil dari penelitian ini bisa menjadi bahan acuan dan pertimbangan bagi sekolahan-sekolahan yang melaksanakan program kelas inklusi.

\section{METODE}

Penelitian ini merupakan jenis penelitian deskriptif. Pendekatan penelitian yang digunakan adalah pendekatan kualitatif. Pelaksanaan penelitian ini dimulai pada bulan April sampai bulan Juli 2017 dengan menggunakan metode observasi, wawancara dan dokumentasi. Informan dalam penelitian ini adalah guru matematika, guru BK, dan beberapa siswa kelas inklusi. 
Analisis data dalam penelitian ini sesuai dengan pendekatan kualitatif yang diajukan dari Miles dan Huberman (Sugiyono, 2009: 247), yakni dilakukan dengan tahap pengumpulan data, reduksi data, penyajian data dan pengambilan kesimpulan atau verifikasi. Langkah-langkah yang dilakukan adalah, pertama-tama peneliti mengumpulkan data baik dari sumber data primer maupun sumber data skunder, bersamaan dengan pengumpulan data sekaligus juga dilakukan penyajian data. Data yang diperoleh dari lapangan maupun bahan pustaka pasti sangat beragam, untuk menyortir agar data yang diperoleh itu sesuai dengan kebutuhan maka dilakukan reduksi data. Reduksi data ini dimaksudkan agar data yang menjadi bahan analisis tersebut adalah data yang benarbenar revelan dengan tema riset yang dilakukan. Selama masa pengumpulan data, dilakukan penyajian dan reduksi data serta verifikasi secara berulang, terus menerus dengan siklus yang tak terputus hingga dapat dilakukan penarikan simpulan. Untuk menguji keabsahan data peneliti menggunakan teknik triangulasi.

\section{HASIL DAN PEMBAHASAN}

Hasil penelitian mengenai studi (pembelajaran) matematika pada kelas inklusi di SMPN 10 Pekalongan adalah sebagai berikut: 1) Pelaksanaan pembelajaran matematika bagi siswa reguler dan siswa berkebutuhan khusus bersama dalam satu kelas. 2) Guru matematika pada pelaksanaan pembelajaran sudah mengkondisikan siswa baik secara fisik maupun psikis. 3) Metode pembelajaran yang digunakan sama antara siswa reguler dan berkebutuhan khusus. 4) Kegiatan evaluasi melalui tes tertulis maupun lisan ketika satu bahasan selesai. Adapun deskripsi pembahasan adalah sebagai berikut:

Kegiatan awal, guru matematika memulai dengan salam, berdoa, selanjutnya mengabsen siswa, tujuan mengabsen adalah untuk meningkatkan kedisiplinan siswa dalam mengikuti pembelajaran dikelas. Pada kegiatan awal ini guru matematika juga memberikan motivasi kepada seluruh siswa supaya lebih bersemangat dalam kegiatan belajar. Guru matematika pada kegiatan ini juga memberikan apersepsi yakni upaya guru untuk mengaitkan materi pelajaran sebelumnya dengan cara memberikan pertanyaanpertanyaan lesan. Baik pertanyaan tersebut diberikan kepada siswa reguler maupun kepada siswa yang berkebutuhan khusus. Kepada siswa berkebutuhan khusus diberikan "jembatan" supaya terpancing untuk bisa menjawab pertanyaan tersebut. Pada kegiatan awal ini guru juga mengkondisikan keadaan kelas, supaya siswa berkebutuhan khusus diusahakan untuk duduk di bangku depan dekat dengan guru, dengan tujuan supaya guru lebih mudah memantau dalam proses pembelajaran nantinya.

Kegiatan inti, guru menyampaikan materi yang diajarkan sesuai dengan apa yang tertulis pada Rencana Pelaksanaan Pembelajaran (RPP). Materi pembelajaran pada kelas inklusi baik untuk siswa reguler maupun siswa berkebutuhan khusus sama saja. 
Perbedaan terletak pada perhatian dan motivasi guru yang diberikan kepada siswa berkebutuhan khusus serta target capaian ketuntasan materi ada sedikit perbedaan antara siswa reguler dengan siswa yang berkebutuhan khusus. Untuk siswa yang kategori ABK pembelajaran lebih kepada pemahaman dasar. Sebagaimana wawancara dengan guru matematika terkait dengan capaian materi bahwa "Sistem pembelajarannya sebenarnya sama dengan kelas lainnya namun untuk ABK akan menghasilkan kuantitas dan kualitas yang berbeda yaitu semisal anak normal memahami materi sampai inti materi atau akarakar dari materi yang diajarkan, sedangkan untuk $A B K$ yang penting paham dasarnya saja itu sudah cukup bagus".

Pelaksanaan pembelajaran matematika kelas inklusi secara keseluruhan sudah sesuai dengan permendiknas no 70 tahun 2009 tentang pendidikan inklusi bagi peserta didik yang memiliki kelainan dan memiliki potensi kecerdasan dan/ bakat istimewa mengenai pelaksanaan pembelajaran di kelas inklusi. Guru matematika selalu memberikan perhatian baik secara fisik maupun psikhis sehingga siswa menerima materi matematika dengan merasa nyaman dan tanpa ada tekanan baik yang dirasakan oleh siswa reguler maupun siswa berkebutuhan khusus.

Kegiatan penutup pembelajaran dilakukan untuk mengetahui penguasaan siswa terhadap kompetensi yang diterapkan pada materi yang disampaikan. Sehingga guru mampu mengetahui kompetensi yang sudah dikuasai dan yang belum dikuasai oleh siswa. Kegiatan yang dilakukan guru adalah dengan memberikan umpan balik berupa pertanyaan secara lisan maupun tertulis. Selain itu guru melakukan kegiatan akhir pembelajaran agar siswa memperoleh gambaran yang utuh tentang pokok-pokok materi yang sudah dipelajarinya. Guru juga memberi kesimpulan dari materi-materi yang sudah dibahas serta sesekali memberikan tugas rumah. Pada tahap ini merupakan acuan untuk mengetahui perkembangan kemampuan siswa khususnya untuk siswa yang berkebutuhan khusus.

Hasil penelitian ini menunjukkan bahwa metode pembelajaran matematika yang diterapkan oleh guru matematika dikelas inklusi beragam dan bervariasi yakni ada metode ceramah, tanya jawab, dan diskusi. Metode ceramah dilakukan oleh guru untuk mempermudah pemahaman siswa terutama terkait dengan konsep-konsep matematika. Penggunaan metode ini juga untuk memberikan penekanan oleh guru terhadap materi yang penting.

Penggalian pemahaman siswa baik reguler maupun berkebutuhan khusus menggunakan metode tanya jawab. Pertanyaan yang diajukan sama untuk siswa reguler dan siswa berkebutuhan khusus. Akan tetapi jika siswa berkebutuhan khusus belum mampu menjawab maka diberi pertanyaan yang lebih mudah. Pada setiap kesempatan siswa berkebutuhan khusus selalu diberi pertanyaan, hal ini sebagai bentuk perhatian khusus dan supaya siswa tersebut aktif. 
Metode diskusi merupakan metode yang diterapkan juga oleh guru dalam proses pembelajaran. Metode ini dilakukan untuk mengaktifkan siswa reguler dan siswa berkebutuhan khusus. Disamping itu tujuan menggunakan metode ini adalah untuk memberi kesempatan kepada siswa untuk saling berbagi pemahaman. Karena terkadang ada siswa yang belum faham tapi malu bertanya pada guru, tapi biasanya dengan sesama siswa tidak malu, untuk mengatasi ini maka guru menggunakan metode diskusi.

Metode pembelajaran yang diterapkan oleh guru SMPN 10 pekalongan bervariasi dengan tujuan untuk memudahkan pemahaman materi oleh siswa. Hal ini sesuai dengan pendapat Suwarna (2006: 105), yang menyatakan bahwa metode pembelajaran yang bisa digunakan dalam kegiatan belajar mengajar yaitu metode ceramah, metode tanya jawab, metode diskusi, metode drill, metode demonstrasi, metode pemberian tugas, metode simulasi, metode karyawisata, metode pemecahan masalah.

Kegiatan evaluasi perkembangan pembelajaran dilaksanakan oleh guru terhadap siswa di kelas inklusi melalui pertanyaan-pertanyaan lesan dan bentuk tertulis. Kegiatan evaluasi ini sebagai alat untuk mengukur sampai dimana kemampuan anak didik menguasai materi yang telah diberikan. Evaluasi bisa dijadikan sekolah sebagai bahan introspeksi diri, dengan melihat sejauh mana kondisi belajar yang telah diciptakan. Penilaian hasil belajar bertujuan untuk melihat kemajuan dan prestasi belajar peserta didik dalam hal penguasaan materi pengajaran yang telah dipelajarinya sesuai denga tujuantujuan yang telah ditetapkan (Ilahi, 2003: 187).

Evaluasi pembelajaran yang dilaksanakan pada kelas inklusi pada SMPN 10 Pekalongan sudah sesuai dengan pelaksanaan pendidikan inklusif sesuai dengan Permendiknas No 70 tahun 2009 pasal 7 sampai 9 bahwa penyelenggaraan pendidikan inklusif dilaksanakan menggunakan kurikulum dengan mengakomodasi kebutuhan dan kemampuan peserta didik seperti minat, bakat dan potensi. Dalam mengevaluasi peserta didik guru dapat menggunakan ulangan harian, ulangan umum dan ujian akhir. Evaluasi harus dilaksanakan sesuai dengan tingkat kemampuan peserta didik, evaluasi pembelajaran dilaksanakan untuk mendiagnosis kesulitan belajar peserta didik termasuk anak berkebutuhan khusus. Evaluasi pembelajaran dilaksanakan selama proses pembelajaran yaitu dapat dilakukan secara tertulis, lisan, dan pengamatan.

Evaluasi yang diberikan oleh guru mempunyai banyak kegunaan bagi siswa, maupun bagi guru itu sendiri. Menurut Asra (2009: 200) hasil tes yang diselenggarakan oleh guru mempunyai kegunaan bagi siswa, diantaranya: 1) Mengetahui apakah siswa sudah menguasai materi pembelajaran yang disajikan oleh guru. 2) Mengetahui bagian mana yang belum dikuasai oleh siswa, sehingga dia berusaha untuk mempelajarinya lagi sebagai upaya perbaikan. 3) Penguatan bagi siswa yang sudah memperoleh skor tinggi dan menjadi dorongan atau motivasi untuk belajar lebih baik. 
Cara penilaian yang dilakukan pada mata pelajaran matematika di SMP N 10 adalah dengan cara tes tertulis. Evaluasi pembelajaran matematika ini dilaksanakan serempak satu kelas seperti pada kelas reguler pada umumnya. Siswa ABK maupun siswa bukan $A B K$ mendapatkan soal yang sama dengan waktu yang bersamaan pula. Dalam evaluasi diadakan pula remedial atau perbaikan. Setelah anak dievaluasi dan hasilnya tidak sesuai dengan standar yang telah ditetapkan, maka guru mengadakan remedial. Remedial ini bukan hanya untuk ABK saja tetapi juga untuk semua anak yang mengikuti tes dan hasilnya tidak atau kurang dari standar yang ditetapkan. Remedial diadakan oleh guru sebagai upaya perbaikan terhadap sesuatu yang dipandang masih belum mencapai apa yang diharapkan atau diarahkan kepada pencapaian hasil belajar yang optimal. Dengan diadakannya remedial tersebut maka diharapkan ada peningkatan prestasi sesuai dengan kriteria keberhasilan yang ditetapkan. Untuk pelaksanaan evaluasi akhir atau tes akhir semester dan atau tes kenaikan kelas dan UAN, siswa ABK mengikuti ujian bersama teman-temannya yang lain. Meskipun ABK mendapatkan perlakuan yang khusus saat pembelajaran, akan tetapi mereka dapat mengikuti ujian bersama teman-temannya yang lain.

\section{SIMPULAN}

Hasil penelitian ini dapat disimpulkan sebagai berikut: 1) Pelaksanaan pembelajaran matematika bagi siswa reguler dan siswa berkebutuhan khusus bersama dalam satu kelas. 2) Guru matematika pada pelaksanaan pembelajaran sudah mengkondisikan siswa baik secara fisik maupun psikis. 3) Metode pembelajaran sama antara siswa reguler dan berkebutuhan khusus. 4) Kegiatan evaluasi melalui tes tertulis maupun lisan ketika satu bahasan selesai.

\section{DAFTAR PUSTAKA}

Asra, S. 2009. Metode Pembelajaran. Bandung: CV Wacana Prima.

Endang, R \& Alimin, Z. 2005. Pengembangan Program. Pembelajaran Individual Bagi Anak Tuna Grahita. Jakarta: Depdiknas.

Erman, S. 2003. Evaluasi Pembelajaran Matematika. Bandung: JICA UPI.

Fitria, R. 2012. Proses Pembelajaran Dalam Setting Inklusi Di Sekolah Dasar. E-Jupekhu (Jurnal IImiah Pendidikan Khusus),1 (1): 90-101.

Hidayat. 2009. Makalah: Model Dan Strategi Pembelajaran ABK Dalam Setting Pendidikan Inklusif. Balikpapan: Parents Support Group (PSG).

Hidayat \& Juang, S. 2016. Desain Pembelajaran Anak Berkebutuhan Khusus dalam Kelas Inklusif. Jurnal JASSI_Anakku, 17 (1): 47-55. 
Illahi, M.T. 2003. Pendidikan Inklusif : konsep dan aplikasi. Jogjakarta: Ar- ruzz media.

Jerami, S, Arcoro. (2007). Pendidikan Berbasis Mutu. Yogyakarta: Pustaka Pelajar.

Peraturan Menteri Pendidikan Nasional Republik Indonesia Nomor 22 Tahun 2006tentang Standar Isi Untuk Satuan Pendidikan Dasar dan Menengah.

Praptiningrum, N. 2010. Fenomena Penyelenggaraan Pendidikan Inklusif Bagi Anak Berkebutuhan Khusus. Jumal Pendidikan Khusus, 7(2): 32-39.

Syaiful, S. 2006. Konsep dan Makna Pembelajaran. Bandung: Alfabeta.

Suwarna. 2006. Pengajaran Mikro.Yogyakarta: Tiara Wacana.

Sugiyono. 2009. Metode Penelitian Kuantitatif, Kualitatif dan $R \& D$. Bandung: Alfabeta.

Tarjiah, I. 2015. Pengembangan Model Pembelajaran Matematika Bagi Siswa Berkesulitan Belajar Di Sekolah Dasar Inklusi. Jurnal IImiah Visi PPTK Paudni, 10(2): 102-113.

Wiyani. 2014. Buku ajar Penanganan Anak Usia Dini Berkebutuhan Khusus. Yogyakarta : Arruz Media. 